\title{
Hepatitis CVirus Load in Seropositive Liver and Kidney Transplant Recipients by Quantitative Real-Time PCR Before and After Transplantation
}

\author{
Mohammad Amin Behzadi ${ }^{1}$, Mazyar Ziyaeyan ${ }^{1, *}$ \\ ${ }^{1}$ Professor Alborzi Clinical Microbiology Research Center, Namazi Hospital, Shiraz University of Medical Sciences, Shiraz, IR Iran \\ *Corresponding author: Mazyar Ziyaeyan, Professor Alborzi Clinical Microbiology Research Center, Namazi Hospital, Shiraz University of Medical Sciences, 7193711351, Shiraz, IR Iran. \\ Tel: +98-7116474304, Fax:+98-7116474303, E-mail: ziyaeyanm@sums.ac.ir.
}

Received: July 23, 2012; Revised: November 10, 2012; Accepted: December 15, 2012

\begin{abstract}
Background: Hepatitis C virus (HCV) infection is one the major health concern among the infected transplant patients. Considering several complications of the disease in them, pre and post-transplantation studies should be performed for monitoring of the infection, as well as, developing new treatment protocols.

Objectives:The current study was conducted to determine the Hepatitis C Virus RNA level among seropositive liver and kidney transplant recipients in Namazi Hospital; the main transplantation center in southern Iran.

Materials and Methods: RNAs were extracted from 105 serum samples of seropositive liver and kidney transplant recipients and analyzed by Real-time PCR assay using a set of primers.

Results: HCVRNAwas detected in a total of 46/105(43.8\%)recipients'serum samples [39/46(84.8\%) males and 7/46 (15.2\%) females]. Moreover, $8 / 46$ (17.4\%) and 38/46 (82.6\%) were kidney and liver recipients, respectively. The copy number of HCV RNA, measured by the Real-time PCR assay, ranged from $5 \times 102$ to $3.14 \times 109$ copies/mL; Median $2.37 \times 105$ copies/mL and $1.7 \times 103$ to $9.44 \times 104$ copies/mL; Median $2.89 \times 104$ copies/ $\mathrm{mL}$ in liver and renal transplant patients, respectively. The comparison of viral load between liver pre transplant recipients group and post transplant counterpart indicated that the copy number of HCV RNA was significantly higher in the post transplant recipients $(\mathrm{P}=0.033)$. The prevalence of the viral nucleic acid was significantly higher in males than in females $(\mathrm{P}=0.026)$. Similarly, with regards to the age groups, the prevalence of HCV RNA was significantly higher in age group $\geq 45$ years than age group $<45$ years $(\mathrm{P}=0.028)$.

Conclusions: Considering the results, it can be concluded that HCV RNA detection is strongly suggested in transplant patients group to determine the prevalence of the disease and their responses to antiviral therapy and diagnosis of drug resistance. In addition, continuous and regular surveillance of HCV RNA level in such patients is highly recommended in order to better manage the complications of graft loss and reduce the mortality rate. Further studies are needed to find new therapeutic methods to lower the incidence of infection of new healthy allograft tissues in HCV RNA positive recipients.
\end{abstract}

Keywords: Hepatitis C Virus; Viral Load; Transplantation; Iran

\section{Background}

Hepatitis C virus (HCV) is a small, enveloped, positive sense, single stranded RNA virus, which belongs to the Flaviviridae family. The virus has six known genetic groups which differ by more than $30 \%$ of the nucleotide (nt) sequence and have unequal geographic distributions (1). A previous study in Iran indicated that the highest level of infection belongs to 3a followed by $1 \mathrm{a}$ (2). The pathogen is a major cause of chronic hepatitis and infects more than 200 million people worldwide with an estimated global prevalence of $2 \%$. The virus has been also established as an important cause of cirrhosis and hepatocellular carcinoma (3-5). HCV is known as a common indication of liver transplantation in Europe and North America $(6,7)$. In addition, it is still estimated to cause 8 - 10 thousand deaths annually in the United States and is the leading cause of liver transplantation (8). The virus is transmitted primarily during blood transfusions and use of contaminated needles and syringes especially among intravenous drug users, those receiving blood transfusions, and transplant recipients (9).

Patients with Chronic kidney disease are in the high risk group with exposure to HCV during their frequent blood transfusion, nosocomial transmission as well as hemodialysis or at the time of renal transplantation. Furthermore, the infection is known as a factor in mortality and graft loss after renal transplantation (10-14). Tragically, despite the screening of blood products for HCV, the disease is still frequent among the patients with end-stage renal disease in both developed and less-developed countries (15). HCV screening has several potential benefits including effective early treatment and reducing the risk

Implication for health policy/practice/research/medical education:

Authors believe that the findings of the current study could be of interest to the Physicians, Virologist and Microbiologist. Considering these results, continuous and regular surveillance of HCV RNA level in such patients is highly recommended in order to better manage the complications of graft loss and reduce the mortality rate.

Copyright (C) 2013, Ahvaz JundishapurUniversity of Medical Sciences; Published by Kowsar Corp. This is an open-access article distributed under the terms of the Creative Commons Attribution License, which permits unrestricted use, distribution, and reproduction in any medium, provided the original work is properly cited. 
of transmission of HCV infection to others (16-19). In addition, it can be helpful for estimating the prognosis of HCV infection.

During the last decade, serological and molecular diagnostic assays have been frequently used to manage, monitor and characterize the clinical status of HCV infection $(20,21)$. Serological tests such as enzyme immunoassays (EIAs) and enzyme-linked immunosorbent assay (ELISA) are suitable for both diagnosis and screening at-risk populations and are recommended as the initial serological tests for the patients with clinical liver disease. Although the specificity of these tests is high, false-negative results may also occur in immunosuppressed patients such as solid organ transplant recipients, HIV-positive patients, hypo- or aggammaglobulinemia, and in the patients on long-term hemodialysis. Thus, to confirm the results, HCV RNA detection assays should be performed, especially in these patient groups (22-25). Furthermore, serum HCV RNA level indicates the response to antiviral therapy and diagnosis of drug resistance.

\section{Objectives}

The current study aimed to determine the Hepatitis C Virus RNA level among seropositive liver and kidney transplant recipients in Namazi Hospital; the main transplantation center in southern Iran.

\section{Materials and Methods}

\subsection{Study Population}

The study involved 105 transplant recipient patients, with age range between 17 and 82 (mean \pm standard deviation: $46.04 \pm 1.14$ years) who referred to Professor Alborzi Clinical Microbiology Research Center, Namazi Hospital, Fars province, Iran between 2009 and 2011 for the diagnosis of HCV infection. All the recipients were serologically positive for $\mathrm{HCV}$ infection. The patients included 77 (73.3\%) men and 28 (26.7\%) women and were divided into two age groups: group I ( $<45$ years) and group II ( $\geq 45$ years). Of these, 38 (36.2\%) and $67(63.8 \%)$ were the recipients of kidney and liver, respectively. The patients were also classified into two groups: pre transplant recipients (66.7\%) and post transplant recipients (33.3\%).

\subsection{Sampling and RNA Extraction}

Blood samples for harvesting of serum were collected from all the patients and left to clot at room temperature for $3 \mathrm{hrs}$ and subsequently centrifuged. The sera were separated, aliquoted, and stored at $-70^{\circ} \mathrm{C}$ for further studies. For all samples, nucleic acid was extracted from a $200-\mu \mathrm{L}$ volume of sera using a commercially available viral RNA isolation kit (Invitek, Berlin, Germany). A standardized amount of internal control RNA, supplied with the Realtime PCR kit, was added to the lysis buffer to monitor the efficiency of sample extraction, the elimination of reverse transcription and PCR inhibitors, and the cDNA synthesis process. Negative controls were included in the extraction process between every 20 clinical samples.

\subsection{Real-Time RT-PCR}

The commercially available RT-PCR Advanced Kit was used to detect and quantify the HCV nucleic acid in all the samples (PrimerDesign Ltd., Millbrook Technology Campus, Southampton, UK). The sensitivity of this kit is 10 copies of viral RNA per reaction. Considering the dilution factor the sensitivity of the test was 1000 copies of viral RNA per $1 \mathrm{ml}$ serum sample. The procedures were performed according to the directions and recommendations of the manufacturer's manual. The amplification process was performed using TaqMan 1-step RT-PCR master mix reagents (Invitrogen, Carlsbad, CA) in a 7500 Realtime PCR System instrument (Applied Biosystems, USA) as follows: $50^{\circ} \mathrm{C}$ for $20 \mathrm{~min}$ (reverse transcription) and $95^{\circ} \mathrm{C}$ for $10 \mathrm{~min}$ (DNA polymerase activation), followed by 50 cycles of $94^{\circ} \mathrm{C}$ for $10 \mathrm{sec}$ (denaturation) and $60^{\circ} \mathrm{C}$ for $60 \mathrm{sec}$ (annealing and extension).

\subsection{Statistical Analysis}

SPSS for Windows (version 16, SPSS Inc., Chicago, IL, USA) was employed for statistical analysis and the data were considered statistically significant at a two-sided $\mathrm{P}<0.05$. The values of RNA copies/mL in positive patients were initially explored with one-sample Kolmogorov-Smirnov test to find the distribution pattern in the current study population. The distribution is not normal if the difference is significant $(P<0.05)$. Therefore, statistical comparisons (mean $\pm \mathrm{SD}$ ) for HCV RNA level were performed between liver pre transplant recipients group and post transplant one using the Mann-Whitney test. In addition, the association between the prevalence of HCV RNA in post and pre transplant recipients, different sexes and age groups (I and II) were analyzed using Chi-Square test.

\section{Results}

HCV RNA was detected in a total of 46/105 (43.8\%) recipients' serum samples. Of these RNA positive patients, $39 / 46$ (84.8 \%) were male and 7/46 (15.2\%) were female. Moreover, 8/46 (17.4\%) and 38/46 (82.6\%) were kidney and liver recipients, respectively. The copy number of HCV RNA, measured by the Real-time PCR assay, ranged from $5 \times 102$ to $3.14 \times 109$ copies/mL; Median $2.37 \times 105$ copies/ $\mathrm{mL}$ and $1.7 \times 103$ to $9.44 \times 104$ copies/mL; Median $2.89 \times 104$ copies/mL in liver and renal transplant patients, respectively. The results of one-sample Kolmogorov-Smirnov test indicated that the distribution of values of RNA copies/ml patients' sera was not normal $(\mathrm{P}<0.05)$ in the studied population. Thus, nonparametric tests were applied.

The comparison of viral load between liver pre and post transplant recipients groups indicated that the copy number of HCV RNA was significantly higher in the post 
transplant recipients $(P=0.033)$. However, the difference between the prevalence of HCV RNA in pre and post transplant recipients was not statistically significant $(\mathrm{P}>$ $0.05)$. The prevalence of the viral nucleic acid was significantly higher in males than in females $(P=0.026)$. Similarly, with regards to the age groups the prevalence of HCV RNA was significantly higher in group II than group $\mathrm{I}(\mathrm{P}=0.028)$. Figure 1 presents the prevalence of HCV RNA positive recipients in different ages and sexes.

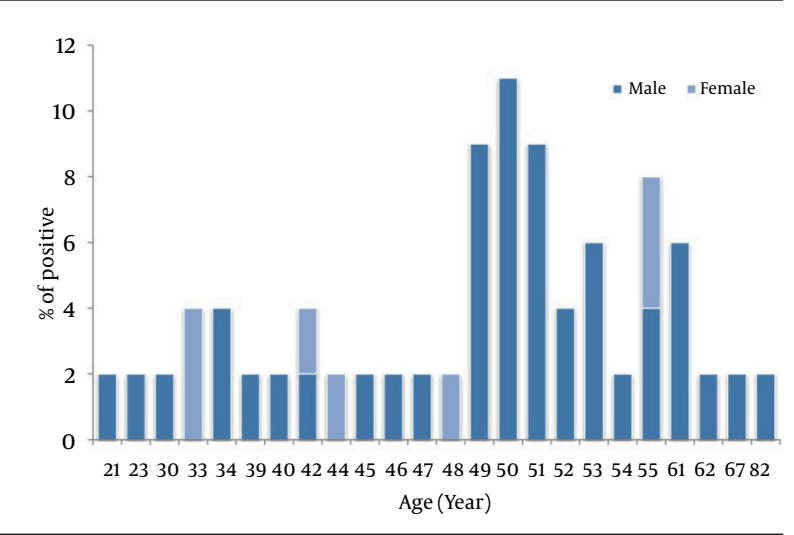

Figure 1. The Prevalence of HCV RNA Positive Recipients in Different Ages and Sexes

\section{Discussion}

In the present study, out of 105 seropositive HCV transplant recipient patients, HCV RNA was detected in $43.8 \%$ of them (69.6\% pre transplant recipients and $30.4 \%$ post transplant ones). Of these HCV RNA positive patients, 17.4\% were kidney recipients and $82.6 \%$ were liver recipients. It can be concluded that about half of these transplant recipient patients may have had active HCV infection. In a previous survey in Iran, HCV RNA was detected in $6.4 \%$ of liver transplant recipients (26). Moreover, the infection in renal transplant recipients varies between $2.6 \%$ and $66 \%$ in different geographical areas of the world (27-29).

The comparison of viral load between liver pre transplant recipients group and post one showed that the copy number of HCV RNA was significantly higher in the post transplant recipients. Previous reports indicated that liver allograft will be reinfected within few hours after transplantation in HCV RNA positive liver recipients, and the majority (>70\%) develop chronic hepatitis. Recurrent $\mathrm{HCV}$ infection post transplantation is a progressive disease which results from the complex interplay between immunosuppression management, viral replication, and the recipient immune system leading to distinct patterns of recurrent chronic HCV in the liver allograft (30). These may be taken on the reasons for the present study results in the liver post transplant recipients.

Transmission of HCV is mainly related to blood transfusion especially among hameodialysis patients or in- travenous drug abuse addicts $(31,32)$. In addition, unprotected sexual contact with infected partner or multi partnership is known as a low measurable risk factor in the transmission of the disease (9). Multi partnership is unusual among females in Islamic countries. In addition, other risk factors such as intravenous illicit drug usage are more common in males than females in Iran. As expected, the results of the present study indicated that the prevalence of HCV RNA was more frequent in male recipients than in females. A recent seroepidemiological study in Colombian population showed that the prevalence of HCV infection was not statistically significant between different age groups (33). Another study in Massachusetts, US, showed an increase in cases of HCV infection among young adults in 2009. However, in 2002 the frequency of the infection was higher among the older age groups (12). The present results revealed that the prevalence of $\mathrm{HCV}$ RNA was significantly higher in age group II than age group I.

It is highly suggested that both kidney and liver transplant recipients and allograft donors should be tested for HCV infection. Earlier studies indicated that both renal and liver recipients with HCV infection had an increased risk of mortality and graft loss, compared with HCV negative group $(12,34)$. It was shown that the rate of mortality and graft failure in HCV infected recipients was 1.69 fold and 1.56 times greater than those of none infected individuals, respectively (35). Although HCV screening serological tests are performed in these transplant recipients, HCV RNA detection is more reliable and the rate of false negative results is significantly lower. On the other hand, serological assays are less sensitive when the rates of anti-HCV antibodies diminish especially in individuals undergoing dialysis $(36,37)$. In addition, monitoring of $\mathrm{HCV}$ nucleic acid level in body fluids indicates the state of the disease, response to medication as well as diagnosis of drug resistance patterns. Consequently, HCV RNA level detection is strongly recommended in this group. In addition, continuous and regular surveillance of HCV RNA level in such patients is highly recommended in order to better manage the complications of graft loss and reduce the mortality rate. Also, comprehensive studies are needed to find new therapeutic methods to reduce the incidence of the infection of new healthy allograft tissues in HCV RNA positive recipients.

To our knowledge, limited research has been performed to demonstrate the prevalence of HCV infection among transplant recipients and donors in Iran, therefore further trials with extended follow up is vital and seems to be helpful for better understanding of the natural history of HCV and the related risk factors in this population.

\section{Acknowledgements}

We are very grateful to Hassan Khajehei, PhD for his linguistic copy editing. 


\section{Authors' Contribution}

None- declared.

\section{Financial Disclosure}

There is no Financial Disclosure.

\section{Funding/Support}

The study was financially supported by Professor Alborzi Clinical Microbiology Research Center.

\section{References}

1. Simmonds P, Alberti A, Alter HJ, Bonino F, Bradley DW, Brechot C et al. A proposed system for the nomenclature of hepatitis $C$ viral genotypes. Hepatology.1994;19(5):1321-4.

2. Ziyaeyan M,Alborzi A, Jamalidoust M, Badiee P, Moeini M, Kadivar A. Prevalence of hepatitis $C$ virus genotypes in chronic infected patients, southern Iran. Jundishapur J Microbiol. 2011;4(3):141-146.

3. Gheorghe L, Csiki IE, Iacob S, Gheorghe C, Smira G, Regep L. The prevalence and risk factors of hepatitis $C$ virus infection in adult population in Romania: a nationwide survey 2006 - 2008. J Gastrointestin Liver Dis. 2010;19(4):373-9.

4. Weigand K, Stremmel W, Encke J. Treatment of hepatitis C virus infection. World J Gastroenterol. 2007;13(13):1897-905.

5. Chen SL, Morgan TR. The natural history of hepatitis $C$ virus (HCV) infection. Int J Med Sci. 2006;3(2):47-52.

6. Berenguer M, López-Labrador FX, Wright TL. Hepatitis C and liver transplantation. J Hepatol. 2001;35(5):666-678.

7. Charlton M. Hepatitis C infection in liver transplantation. Am J Transplant. 2001;1(3):197-203.

8. Sarbah SA, Younossi ZM. Hepatitis C: an update on the silent epidemic. J Clin Gastroenterol. 2000;30(2):125-43.

9. Alvarado-Mora MV, Fernandez MF, Gomes-Gouvea MS, de Azevedo Neto RS, Carrilho FJ, Pinho JR. Hepatitis B (HBV), hepatitis C (HCV) and hepatitis delta (HDV) viruses in the Colombian population--how is the epidemiological situation? PLoS One. 2011;6(4).

10. Meyers CM, Seeff LB, Stehman-Breen CO, Hoofnagle JH. Hepatitis $C$ and renal disease: an update. Am JKidney Dis. 2003;42(4):631-57.

11. Aroldi A, Lampertico P, Montagnino G, Lunghi G, Passerini P, Villa $\mathrm{M}$, et al. Natural history of hepatitis $\mathrm{C}$ virus infection in adult renal graft recipients. Transplant Proc. 2005;37(2):940-1.

12. Fabrizi F, Martin P, Dixit V, Bunnapradist S, Dulai G. Hepatitis $C$ virus antibody status and survival after renal transplantation: meta-analysis of observational studies. Am J Transplant 2005;5(6):1452-61.

13. Pedroso S, Martins L, Fonseca I, Dias L, Henriques AC, Sarmento $\mathrm{AM}$, et al. Impact of hepatitis $\mathrm{C}$ virus on renal transplantation: as sociation with poor survival. Transplant Proc. 2006;38(6):1890-4.

14. Einollahi B, Pourfarziani V, Ahmadzad-Asl M, Davoudi F, LessanPezeshki M, Davoudi A, et al. Iranian model of renal allograft transplantation in 3028 recipients: survival and risk factors. Transplant Proc. 2007;39(4):907-10.

15. Fabrizi F, Poordad FF, Martin P. Hepatitis $C$ infection and the patient with end-stage renal disease. Hepatology. 2002;36(1):3-10.

16. Thomson BJ, Kwong G, Ratib S, Sweeting M, Ryder SD, De Angelis $\mathrm{D}$, et al. Response rates to combination therapy for chronic HCV infection in a clinical setting and derivation of probability tables for individual patient management. JViral Hepat. 2008;15(4):271-

17. Hayashi N, Takehara T. Antiviral therapy for chronic hepatitis $\mathrm{C}$ : past, present, and future. J Gastroenterol. 2006;41(1):17-27.

18. Gordon FD. Cost-effectiveness of screening patients for hepatitis
C. Am JMed.1999;107(6B):36S-40S.

19. Hill L, Henry B, Schweikert S. Screening for chronic hepatitis C: American College of Preventive Medicine practice policy statement. Am J Prev Med. 2005;28(3):327-30.

20. Alavi SM, Hajiani E. Hepatitis C infection: a review on epidemiology and management of occupational exposure in health care workers for general physicians working in Iranian health network setting. Jundishapur J Microbiol. 2011;4(1):1-9.

21. Ziyaeyan M, Jamalidoust M, Moeini M. Evaluation of Hepatitis C Virus Infection in Antibody Positive Orphan Newborns. Jundishapur J Microbiol. 2012;6(1):72-75

22. Thio CL, Nolt KR, Astemborski J, Vlahov D, Nelson KE, Thomas DL. Screening for hepatitis $C$ virus in human immunodeficiency virus-infected individuals. J Clin Microbiol. 2000;38(2):575-7.

23. Kalantar-Zadeh K, Miller LG, Daar ES. Diagnostic discordance for hepatitis $\mathrm{C}$ virus infection in hemodialysis patients. Am J Kidney Dis. 2005;46(2):290-300.

24. Albeldawi M, Ruiz-Rodriguez E, Carey WD. Hepatitis C virus: Prevention, screening, and interpretation of assays. Cleve Clin JMed 2010;77(9):616-26.

25. Ghany MG, Strader DB, Thomas DL, Seeff LB. Diagnosis, management, and treatment of hepatitis C: an update. Hepatology. 2009;49(4):1335-74.

26. Ebadi M, Yaghobi R, Geramizadeh B, Bahmani MK, MalekHosseini SA, Nemayandeh M. Prevalence of HCV and HGV infections in Iranian liver transplant recipients. Transplant Proc. 2011;43(2):618-20.

27. Moghaddam SM, Alavian SM, Kermani NA. Hepatitis C and renal transplantation: a review on historical aspects and current is sues. Rev Med Virol. 2008;18(6):375-86.

28. Fehr T, Riehle HM, Nigg L, Gruter E, Ammann P, Renner EL, et al. Evaluation of hepatitis $B$ and hepatitis $C$ virus-infected renal allograft recipients with liver biopsy and noninvasive parameters. Am J Kidney Dis. 2003;42(1):193-201.

29. Mitwalli AH, Alam A, Al-Wakeel J, Al Suwaida K, Tarif N, Schaar TA, et al. Effect of chronic viral hepatitis on graft survival in Saudi renal transplant patients. Nephron Clin Pract. 2006;102(2):c72-80.

30. Demetris AJ. Evolution of hepatitis C virus in liver allografts. Liver Transpl. 2009;15 Suppl 2:S35-41.

31. Murphy EL, Bryzman SM, Glynn SA, Ameti DI, Thomson RA, Williams $\mathrm{AE}$, et al. Risk factors for hepatitis $\mathrm{C}$ virus infection in United States blood donors. NHLBI Retrovirus Epidemiology Donor Study(REDS). Hepatology. 2000;31(3):756-62.

32. Ashry Ahmed Gheith O. Dilemma of HCV infection in renal trans plant recipients. Int J Nephrol. 2011;2011:471214.

33. Hepatitis C virus infection among adolescents and young adults:Massachusetts, 2002-2009. MMWR Morb Mortal Wkly Rep. 2011;60(17):537-41.

34. Fabrizi F, Martin P, Dixit V, Bunnapradist S, Dulai G. Hepatiti $C$ virus antibody status and survival after renal transplantation: meta-analysis of observational studies. Am J Transplant. 2005;5(6):1452-61.

35. Fabrizi F, Lunghi G, Dixit V, Martin P. Meta-analysis: anti-viral therapy of hepatitis $C$ virus-related liver disease in renal transplant patients. Aliment Pharmacol Ther. 2006;24(10):1413-22.

36. Rostami Z, Nourbala MH, Alavian SM, Bieraghdar F, Jahani Y Einollahi B. The impact of Hepatitis $C$ virus infection on kidney transplantation outcomes: A systematic review of 18 observational studies: The impact of HCV on renal transplantation. Hepat Mon. 2011;11(4):247-54.

37. Terrault NA, Adey DB. The kidney transplant recipient with hepatitis C infection: pre- and posttransplantation treatment. Clin Am Soc Nephrol. 2007;2(3):563-75.

38. Lok AS, Ma OC, Chan TM, Lai CL, Chung HT, Ng CP, et al. Overestimation of the prevalence of antibody to hepatitis $C$ virus in retrospective studies on stored sera. Hepatology. 1991;14(5):756-62. 